\title{
Some aspects of the biology and ecology of Knipowitschia caucasica (Teleostei: Gobiidae) in the Evros Delta (North Aegean Sea)
}

\author{
T. Kevrekidis, A. K. Kokkinakis \& A. Koukouras \\ Department of Zoology, University of Thessaloniki; Box 134, \\ GR-54006 - Thessaloniki, Greece
}

\begin{abstract}
Some aspects of the biology and ecology of the goby Knipowitschia caucasica were studied over a period of 13 months in a poly- to euhaline area in the Evros Delta (North Aegean Sea). This fish grows rapidly in the summer and autumn after hatching, matures after its first winter, breeds from the end of April to the end of July, and grows rapidly again in July - September. The older males perish after their second February, whereas some females have a second breeding season at the end of April/beginning of May, shortly before their death. The fish grows to about $40 \mathrm{~mm}$ in total length. There is a positive correlation between the total length (TL) and the standard length (SL) or the cleaned body weight (CW). SL increases slower than TL, whereas CW increases slower than TL in immature individuals and faster in males and females. There is no difference between immature individuals, males and females, in the growth rate of SL, TL and CW, TL. The mean monthly values of the condition factor varies from 0.289 to 0.576 in females and from 0.313 to 0.548 in males. The overall sex ratio of females to males is $1: 1.46$. Fecundity ranges from 60 to 217 eggs with a mean value of 109.8 and depends upon size, whereas relative fecundity varies between 968 and 2170 with a mean of 1558 . The fish feeds predominantly on benthic amphipods and polychaetes.
\end{abstract}

\section{INTRODUCTION}

Knipowitschia Iljin, 1927, a gobiid genus of Ponto-Caspian origin, is of special biogeographical interest due to the way it is distributed in the Mediterranean Sea (Miller, 1972). This genus is represented by two species in the Mediterranean Sea: the native species $K$. panizzae (Verga, 1841), the presence of which is limited mainly to the coasts and the inland waters of the Italian Peninsula (e.g. Miller, 1972; Tortonese, 1975; Zerunian \& Gandolfi, 1986) and to the islands of the Ionian Sea (Papaconstantinou, 1988), and K. caucasica (Kawrajsky, in Berg, 1916) which is widespread in the Ponto-Caspian region. $K$. caucasica is also known from other regions such as the Aral Sea (e.g. Baimov, 1963), the Sea of Marmara (e.g. Gheorghiev, 1964), the North Aegean Sea (e.g. Gheorghiev, 1964; Papaconstantinou \& Tortonese, 1980), the inland waters of the Western Thrace (e.g. Economidis, 1974) and Macedonia (Economidis \& Sinis, 1982; Economidis \& Voyadjis, 1985), as well as from the Adriatic Sea (e.g. Miller, 1972). This distribution of $K$. caucasica in the Mediterranean Sea seems to be a result of its euryhaline character; it can live both in fresh and in hyperhaline waters, although it prefers the shallow waters of the mesohaline and hyperhaline coastal lakes and lagoons (Gheorghiev, 1964, 1966; Troitskii \& Tsunikova, 1978). 
Information on the biology of $K$. caucasica is restricted, and concerns exclusively the populations of the Ponto-Caspian region and the Aral Sea. This information has usually been published in the form of brief notes, mainly by Koblitskaya (1961) (cited in Baimov, 1963), Baimov (1963), Gheorghiev (1964, 1966), Troitskii \& Tsunikova (1978), Ragimov (1986), etc. No information exists on the Mediterranean populations of this species.

The information on the biology of the other species of this genus is also very poor and has been given mainly by Gheorghiev (1966), Gandolfi (1972), Zelenin \& Vladimirov (1975), Ragimov (1986). In the present paper, an attempt is made to compare the above information with that collected from the study of the $K$. caucasica population in the area of the Evros Delta.

\section{THE ECOSYSTEM OF THE STUDIED POPULATION}

The sampling area, a natural channel about $2 \mathrm{~km}$ long, $60 \mathrm{~m}$ wide and $3 \mathrm{~m}$ deep, is representative of the inner regions of the Evros Delta (north eastern Greece). The channel is isolated from an adjacent lagoon by an embankment which prevents direct communication. Along the channel banks and in depths seasonally varying between 0.3 and $1.0 \mathrm{~m}$, there exist two zones with formations of the polychaete Ficopomatus enigmaticus (Fauvel). These zones are both $0.7 \mathrm{~m}$ wide. According to observations made by Kevrekidis (1988) and Kevrekidis \& Koukouras (1989, in press) during the sampling period (Feb. 1983 - Feb. 1984), the gastropod Hydrobia salaria (Radoman), the amphipod Gammarus aequicauda (Martynov), the bivalve Abra ovata (Philippi) and the polychaete Hediste diversicolor (O. F. Müller) were the dominant species of the benthic macrofauna associated with the $F$. enigmaticus formations on the southeastern bank of the channel: On the substrate, around the $F$. enigmaticus formations, numerous empty shells were found belonging to the bivalve Cerastoderma glaucum (Bruguiére).

In the channel, water salinity varied between $32.5 \%$ and $36.0 \%$ during the period February - October 1983 , and between $24.0 \%$ and $27.0 \%$ during the period November 1983 - February 1984 ; water temperature varied from $3.4^{\circ} \mathrm{C}$ (Dec. 1983) to $26.9^{\circ} \mathrm{C} \mathrm{(Jul.}$ 1983); dissolved $\mathrm{O}_{2}$ from $5.3 \mathrm{ppm}$ (Oct. 1983) to $8.4 \mathrm{ppm}$ (Dec. 1983); $\mathrm{pH}$ from 7.3 to 8.3 ; median diameter of the sediment (Md) from $63 \mu \mathrm{m}$ to $104 \mu \mathrm{m}$ (very fine sand), and sediment organic matter from $0.90 \%$ to $1.30 \%$ (Kevrekidis 1988; Kevrekidis \& Koukouras, 1989 , in press).

\section{MATERIAL AND METHODS}

From February 1983 to February 1984, monthly samples of Knipowitschia caucasica were taken from the southeastern zone of the Ficopomatus enigmaticus formations. Each time, a $1-\mathrm{mm}$ mesh special net (with a square opening, each side measuring $40 \mathrm{~cm}$ ) was pulled twice in the polychaete zone over a distance of $10 \mathrm{~m}$. All fish collected were preserved in a $5 \%$ formalin solution immediately after capture.

In the laboratory, the fish were measured to the nearest $0.1 \mathrm{~mm}$, weighted to the nearest $\mathrm{mg}$ and sexed. Gonad and guts were removed, and the fish reweighted to the nearest $\mathrm{mg}$ after that removal. The gonads and the gut contents were examined under microscope. Each ripe ovary was damp-dried on filter paper, and the number of oocytes it contained were counted (Bagenal \& Braum, 1971). All the individuals were grouped in 2$\mathrm{mm}$ size classes; the inter-class interval was selected by the method of Goulden (1952), 
reported by Cancela da Fonseca (1965). The fish population was analysed by the graphical analysis of polymodal frequency distributions (Harding, 1949). This method is convenient for the age determination of the youngest age-groups of fish in general (Tesch, 1971), and consequently of the whole of the age-groups of fish having a short life span. Moreover, the small and ctenoid scales of many individuals of $K$. caucasica were examined under the microscope (Lagler, 1972) to confirm the graphical analysis results.

\section{RESULTS}

\section{Population structure}

A total of 397 individuals of Knipowitschia caucasica were examined during this study. The population composition of each sample over the period February 1983 to February 1984 is illustrated in Figure 1 by histograms based on frequency distributions showing the demographic development of the population in this species. The composition of the March and June samples is not represented, since just a few individuals were collected during these months. Total length is used in frequency distributions; total length as well as standard length could be used, because there is no difference in the relative growth of standard length/total length between immature individuals, males and females (see below).

By means of the graphic analysis of the frequency distributions, we delimited three size groups during the study period, which we called A, B and C (Fig. 2). From Figure 2, we can say that young fish appear in June - August and have a maximum life span of about two years. Examination of scales from individuals of $\mathrm{A}$ and $\mathrm{B}$ size groups taken by random sampling, and from all individuals of $C$ size group, revealed that $A, B$ and $C$ size groups can be characterized as $0, \dot{I}$ and II age groups, respectively. Young fish appeared in June - August in two parts $\left(A_{1}\right.$ and $\left.A_{2}\right)$, perhaps due to successive spawnings in the same year. Such observations have been made on other gobiid species by Claridge et al. (1985); moreover, it is known that $K$. caucasica populations are characterized by two batch spawning (Troitskii \& Tsunikova, 1978; Ragimov, 1986). $\mathrm{A}_{1}$ and $\mathrm{A}_{2}$ parts united in November, since the growth of the smaller part was faster (Fig. 2). The participation percentages of the size group A presented an unexpected decrease during December 1983 - February 1984 (Fig. 2). This event may be attributed to a greater migration of the young fishes to deeper waters of the channel; it is known that other populations of $K$. caucasica descend to deeper waters $(1.5-2.0 \mathrm{~m}$ ) during the winter period (Baimov, 1963). Size group C in April 1983 and size group B in February 1984, shortly before their disappearance, seemed to be divided in two parts. This separation may be attributed to the death of some individuals of the intermediate size classes; these individuals are probably males (see below).

\section{Growth}

\section{Size}

The largest individual obtained was a female of $41.1 \mathrm{~mm}$ total length $(34.8 \mathrm{~mm}$ standard length); the largest male had a total length of $29.1 \mathrm{~mm}(24.3 \mathrm{~mm}$ standard length). These fishes belonged to $C$ and $B$ size group, respectively. Moreover, the mean total length as well as the mean standard length of females were greater than those of 

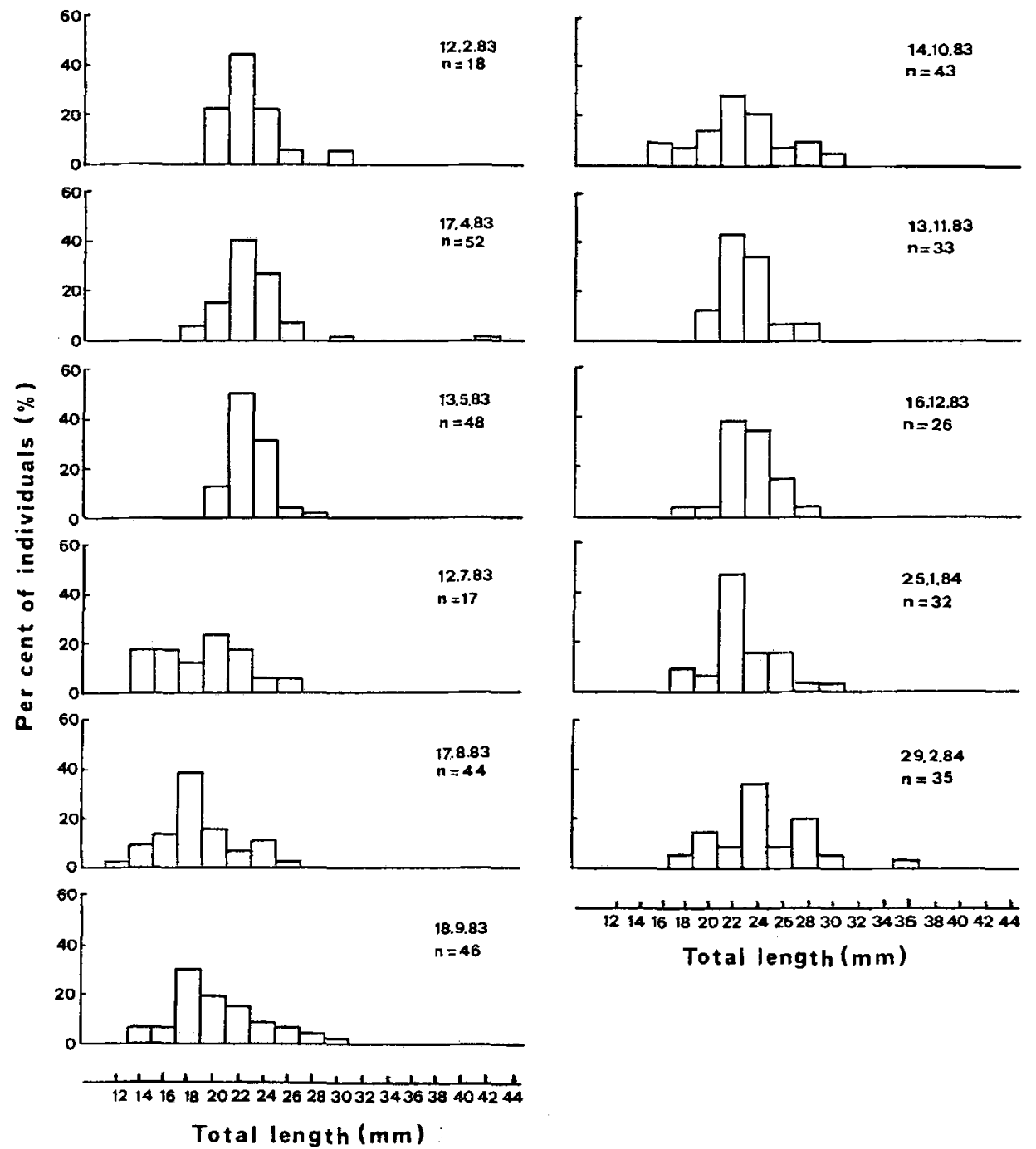

1214161820222426283032343638404244

Total length ( $\mathrm{mm}$ )

Fig, 1. Length-frequency histograms of Knipowitschia caucasica from 12 February 1983 to $29 \mathrm{Fe}-$ bruary 1984 in the Evros Delta (North Aegean Sea)

males (Table 1). The smallest mature fish measured $14.5 \mathrm{~mm}$ total length $(12.0 \mathrm{~mm}$ standard length). The size of immature individuals varied between $12.8 \mathrm{~mm}$ and $17.0 \mathrm{~mm}$ total length (or between $10.6 \mathrm{~mm}$ and $13.4 \mathrm{~mm}$ standard length). The maximum total and cleaned weight of females reached $0.624 \mathrm{~g}$ and $0.474 \mathrm{~g}$ respectively, whereas the maxima for males were $0.169 \mathrm{~g}$ and $0.138 \mathrm{~g}$ respectively. 


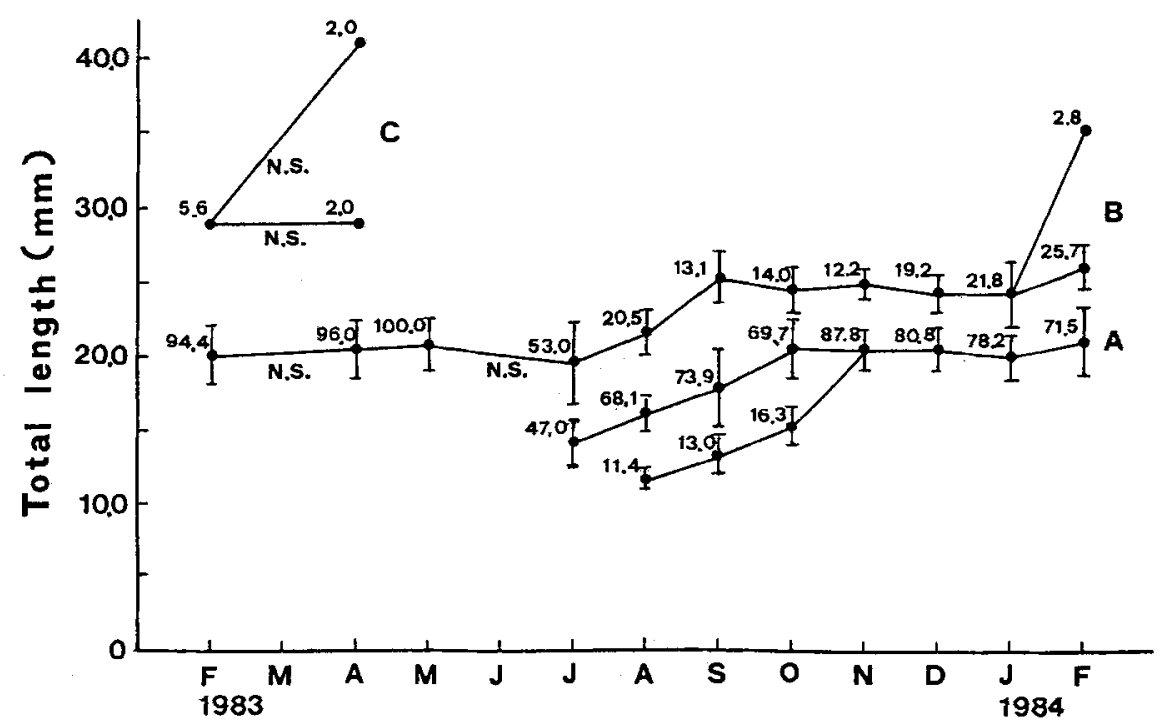

Fig. 2. Development in time of the size groups of Knipowitschia caucasica; dots = mean total length; bar lines = standard deviation; numbers = percentages of size groups in the total population; N.S. = no sample

Total length (TL) - standard length (SL) relationship

The dispersion diagram of SL in relation to TL for, the whole fish population is illustrated in Figure 3A. Searching for the best description of the relation SL/TL, we arrived at the linear relation $\mathrm{SL}=\mathrm{b}+\alpha \cdot \mathrm{TL}$ (where $\alpha, \mathrm{b}$ are constants) which additionally showed the highest positive coefficient of correlation.

A positive correlation was found to exist between the criterions SI and TL ( $r=0.935$; $\mathrm{N}=397$ ) (Table 1) for the whole fish population (Fig. 3A); a negative allometry was found for the relations SL, TL since $\alpha<1(\alpha=0.847)$ (Table 1), i.e. the standard length increases more slowly than the total length. Tests were carried out for any statistical differences in the relative growth of SL, TL between immature individuals, males and females; in all these cases the morphometric criterions SL, TL showed a negative allometry since $\alpha<1$ (Table 1). Comparing the slopes of males and females, and those of immature and mature fish (males or females) (Table 1) using the method of Mayrat (1965), it was found that there were no statistical differences.

\section{Total length (TL) - cleaned weight (CW) relationship}

Searching for the best description of the relation, cleaned weight (weight of the body less gut and gonad) - total length, we arrived at the equation $\mathrm{CW}=\mathrm{b} \cdot(\mathrm{TL})^{\alpha}$ (Le Cren, 1951) which additionally showed the highest positive coefficient of correlation; this is clearly shown in the dispersion diagram (Fig. 3B). That formula, which was transformed to: $\log _{10} C W=\alpha \cdot\left(\log _{10} T L\right)+\log _{10} b$ (where $\alpha, b$ are constants), was used according to Tesch (1971).

A positive correlation exists between the criterions $\log _{10} \mathrm{CW}$ and $\log _{10} \mathrm{TL}(\mathrm{r}=0.826$; 

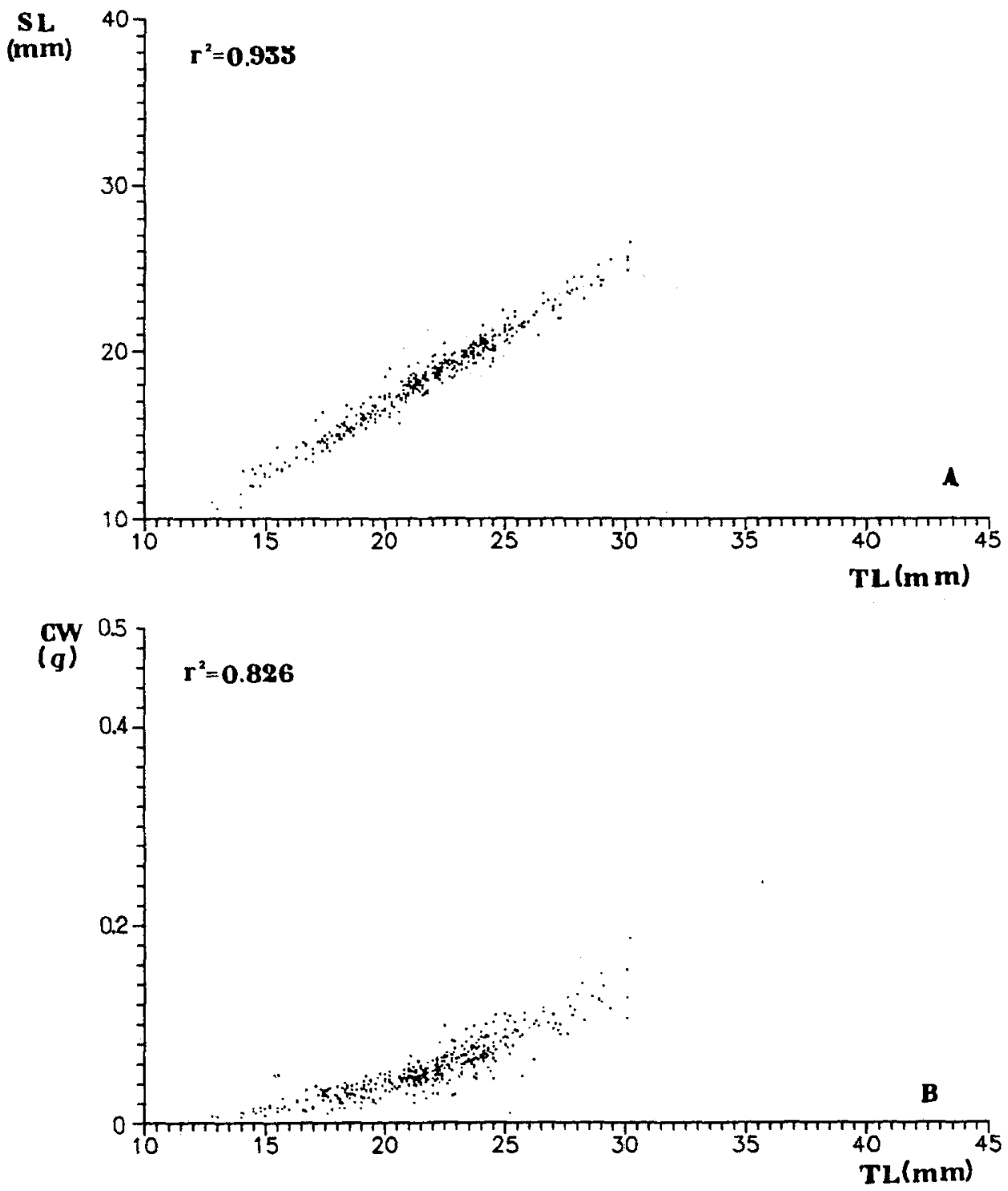

Fig. 3. A: Dispersion diagram of SL (standard length in $\mathrm{mm}$ ) in relation to TL (total length in $\mathrm{mm}$ ) in 397 animals of Knipowitschia caucasica; B: Dispersion diagram of CW (cleaned weight in $\mathrm{g}$ ) in relation to TL (total length in $\mathrm{mm}$ ) in 397 animals of $K$. caucasica

$\mathrm{N}=397$ ) (Table 2) for the whole population of Knipowitschia caucasica (Fig. 3B); those morphometric criterions showed a positive allometric growth since $\alpha>3(\alpha=3.456)$ (Table 2), which means that "the fish becomes heavier for its length as it grows larger" (Tesch, 1971).

It was tested whether there existed a statistical difference in the relative growth of 
Table 1. Estimation of statistical parameters of the population of Knipowitschia caucasica. $\alpha, b=$ constants; $\mathrm{TL}=$ total length in $\mathrm{mm} ; \mathrm{SL}=$ standard length in $\mathrm{mm}_{;} \mathrm{s}=$ standard deviation; $\mathrm{r}=$ coefficient of correlation; $\mathrm{N}=$ number of animals

\begin{tabular}{|c|c|c|c|c|}
\hline & Whole population & Immature fish & Males & Females \\
\hline$\alpha \pm \mathrm{s} \alpha$ & $0.847 \pm 0.011$ & $0.686 \pm 0.164$ & $0.837 \pm 0.020$ & $0.853 \pm 0.012$ \\
\hline $\mathrm{b} \pm \mathrm{sb}$ & $-0.032 \pm 0.250$ & $2.063 \pm 2.385$ & $0.224 \pm 0.441$ & $-0.198 \pm 0.280$ \\
\hline$\overline{\mathrm{TL}} \pm \mathrm{sTL}$ & $21.930 \pm 3.440$ & $14.480 \pm 1.350$ & $21.560 \pm 2.940$ & $22.890 \pm 3.590$ \\
\hline$\overline{\mathrm{SL}} \pm \mathrm{sSL}$ & $18.540 \pm 3.020$ & $12.000 \pm 1.100$ & $18.250 \pm 2.620$ & $19.340 \pm 3.110$ \\
\hline $\mathrm{r}^{2}$ & 0.935 & 0.714 & 0.882 & 0.970 \\
\hline $\mathrm{N}$ & 397 & 9 & 230 & 158 \\
\hline
\end{tabular}

Table 2. Estimation of statistical parameters of the population of Knipowitschia caucasica. $\alpha, b=$ constants; $\log =\log _{10} ; \mathrm{TL}=$ total length in $\mathrm{mm} ; \mathrm{CW}=$ cleaned weight in $\mathrm{g} ; \mathrm{s}=$ standard deviation; $r=$ coefficient of correlation; $N=$ number of animals

\begin{tabular}{|c|c|c|c|c|}
\hline & Whole population & Immature fish & Males & Females \\
\hline$\alpha \pm \mathrm{s} \alpha$ & $3.456 \pm 0.080$ & $2.790 \pm 1.157$ & $3.246 \pm 0.126$ & $3.430 \pm 0.112$ \\
\hline $\log b \pm s \log b$ & $-5.928 \pm 0.107$ & $-5.297 \pm 1.342$ & $-5.641 \pm 0.168$ & $-5.896 \pm 0.152$ \\
\hline$\overline{\log T L} \pm$ sLogTL & $1.336 \pm 0.069$ & $1.159 \pm 0.040$ & $1.329 \pm 0.061$ & $1.355 \pm 0.067$ \\
\hline$\overline{\log C W} \pm \mathrm{sLogCW}$ & $-1.313 \pm 0.263$ & $-2.063 \pm 0.164$ & $-1.327 \pm 0.229$ & $-1.250 \pm 0.246$ \\
\hline$\Sigma \log \mathrm{TL}^{2}$ & 710.020 & 12.104 & 407.340 & 290.580 \\
\hline$\Sigma \log T L . \log C W$ & -689.530 & -21.489 & -402.920 & -265.120 \\
\hline$\Sigma \log \mathrm{CW}^{2}$ & 711.760 & 38.515 & 416.890 & 256.350 \\
\hline$r^{2}$ & 0.826 & 0.454 & 0.745 & 0.858 \\
\hline $\mathbf{N}$ & 397 & 9 & 230 & 158 \\
\hline
\end{tabular}

$\log _{10} \mathrm{CW}$ in relation to $\log _{10}$ TL between immature fish, males and females. In mature fish (males or females), the cleaned body weight increases faster than the total length, since $\alpha>3$ (Table 2). Comparing the regression equations of males and females (Table 2) with the use of a t-testing procedure (Zar, 1984), it was found that they had neither different slopes $(\alpha)$ nor different elevations $\left(\log _{10} b\right)$, which means: $(1)$ the growth rate in females is similar to that of males, (2) the females are as heavy for their length as the males. In immature individuals, on the contrary, the cleaned body weight increases more slowly than the total length, since $\alpha<3$ (Table 2). Nevertheless, on comparing the slopes of immature and mature fish (males or females), no statistical difference was found. A difference was only found between the elevations $(p<0.001)$.

\section{Seasonal variation of growth}

Knipowitschia caucasica exhibits a seasonal variation in growth rate. The growth curve of the size groups (Fig. 2) reveals that the main growing period for the B group lasts from July until September, and for the A group from July - August until October November; the mean total length ( \pm standard deviation) of the A group in July and November was $13.8( \pm 1.5) \mathrm{mm}$ and $20.4( \pm 1.3) \mathrm{mm}$ respectively, and that of the $B$ group in July and September was $19.6( \pm 2.8) \mathrm{mm}$ and $25.3( \pm 1.6) \mathrm{mm}$ respectively. During the 
rest of the year, little increase in length takes place; the individuals which have overwintered are almost the same size as the autumn ones.

\section{Condition factor}

The condition factor was calculated on the basis of cleaned weight from the relationship

$$
\mathrm{k}=\frac{\mathrm{CW}}{\mathrm{TL}^{3}} \cdot 10^{5}
$$

(Nikolsky, 1963), where $\mathrm{k}=$ condition factor, $\mathrm{CW}=$ cleaned weight in $\mathrm{g}$ and $\mathrm{TL}=$ total length in $\mathrm{mm}$. The seasonal variation in condition factor of males and females throughout the year is almost similar and is shown in Figure 4 . The mean monthly $k$ values varied from 0.289 (Feb. 1983) to 0.576 (Aug. 1983) in females and from 0.313 (Feb. 1983) to 0.548 (Aug. 1983) in males. No statistical difference was found between mean monthly $\mathrm{k}$ values of females and males ( $5 \%$ level Mann-Whitney U-test); i.e. females are as heavy for their length as males. Males $k$ values actually exceed those of females in April - May only. The

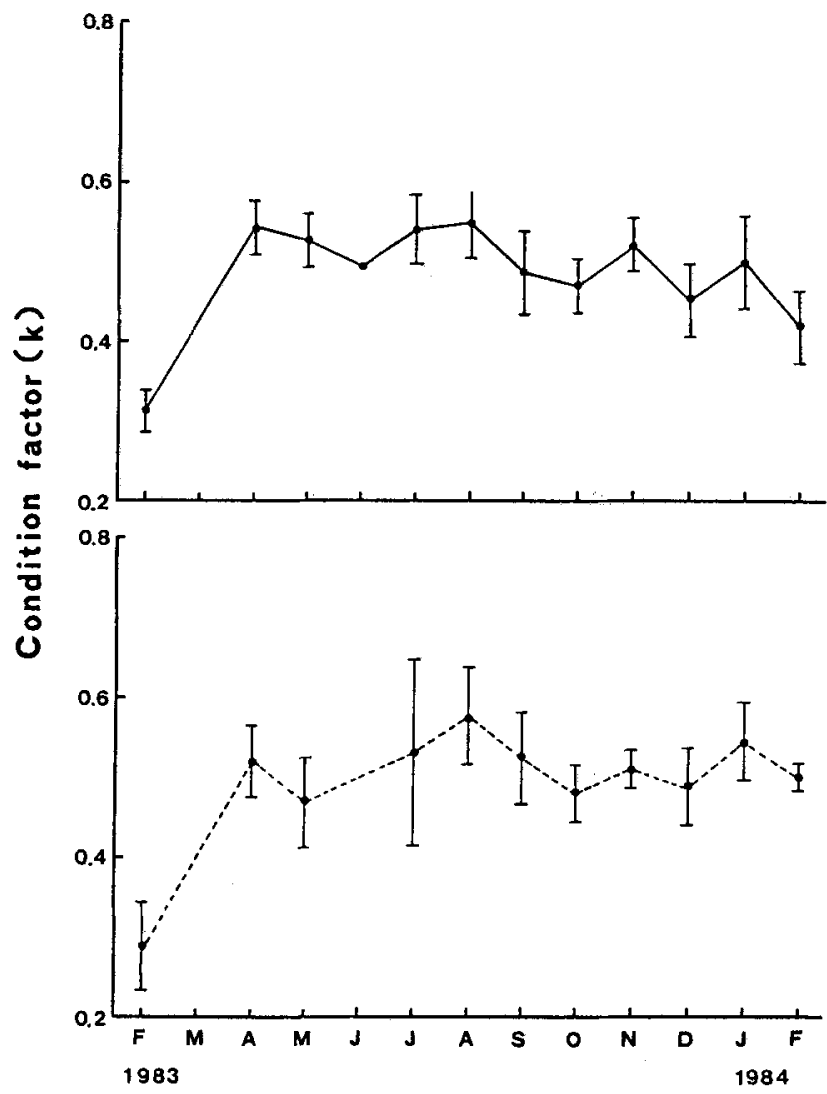

Fig. 4. Seasonal variation in condition factor of males (above) and females (below) of Knipowitschia caucasica throughout the year; dots $=$ mean values; bar lines $=95 \%$ confidence limits 
seasonal variation of $\mathrm{k}$ values is characterized by a gradual increase from February to April, a decrease until June, which is to be expected as it coincides with the main reproductive period (see below) (Lagler, 1972), and following this, there is a new increase in July - August. A decrease in $\mathrm{k}$ values follows until October, and a successive increase and decrease until the end of the period of study.

\section{Reproduction and fecundity}

The overall sex ratio of females to males is $1: 1.46$. This preponderance of males is higher in the A size group $(1: 1.48)$ than it is in the B size group $(1: 1.44)$; in the $C$ size group (two-year old individuals) there are only females. Consequently, it seems that females live slightly longer than males do.

Immature fish were collected during August - September only. After April, almost all individuals were found in a stage of maturity with reproduction imminent, according to the classifications of Nikolsky (1963) and Kesteven (1960) (cited in Bagenal \& Braum, 1971). Ripe females and males were obtained from April to July. The reproduction period begins at the end of April/beginning of May and continues until the end of July. Almost all of the thirteen ripe females collected belong to the B size group except a 2-year old one which was collected in April; that ripe female was the largest and heaviest $(29.4 \mathrm{~mm}$ total length, $0.198 \mathrm{~g}$ total weight and $0.116 \mathrm{~g}$ cleaned weight). The minimum value of total length (TL), total weight (TW) and cleaned weight (CW) of the ripe females was $21.0 \mathrm{~mm}, 0.074 \mathrm{~g}$ and $0.042 \mathrm{~g}$, respectively.

The fecundity $(F)$ of the thirteen ripe females ranged from 60 to 217 eggs with a mean of 109.8 ( \pm 56.3 standard deviation). There is a positive correlation between $\log _{10} F$ and $\log _{10} \mathrm{TL}\left(\mathrm{r}^{2}=0.545\right)$ (Fig. 5A), $\log _{10} \mathrm{~F}$ and $\log _{10} \mathrm{TW}\left(\mathrm{r}^{2}=0.835\right.$ ) (Fig. 5B), and $\mathrm{F}$ and $\mathrm{CW}$ $\left(r^{2}=0.771\right)$ (Fig. $\left.5 \mathrm{C}\right)$. The regression equations for the data are the following: $\log _{10} \mathrm{~F}=$ 3.69. $\log _{10} \mathrm{TL}-3.04, \log _{10} \mathrm{~F}=1.33 \cdot \log \mathrm{TW}+3.28$, and $\mathrm{F}=2028 \cdot \mathrm{CW}-30.0$, respectively. In the relation $\mathrm{F}: \mathrm{CW}$, the linear and not the exponential equation was used because it showed the highest coefficient of correlation. We should mention that fecundity shows the highest correlation with total weight and a relatively lower correlation with total length, something ascertained also by Nikolsky (1969).

The relative fecundity $(\mathrm{RF})$, which expressed the number of oocytes per $\mathrm{g}$ cleaned weight of a female (Nikolsky, 1969), ranged from 968 to 2170 with a mean of $1558( \pm 395$ standard deviation). However, no correlation was found between relative fecundity and the morphometric criterions TL, TW and CW ( $p>0.05)$.

\section{Food}

The diet of Knipowitschia caucasica was analysed for each size group separately (Table 3). Food organisms were recorded according to the number and percentage of stomachs containing one or more individuals of each food category (occurrence method), and number and percentage of individuals in each food category for all stomachs (numerical method) (Hyslop, 1980). The percentage of empty stomachs in the A size group $(60.7 \%)$ is higher than it is in the B size group (43.7\%). Three specimens of the C size group examined did not contain ingested material. The fish diet is characterized by a restricted variety, including only six food categories. In the B size group the predominant 

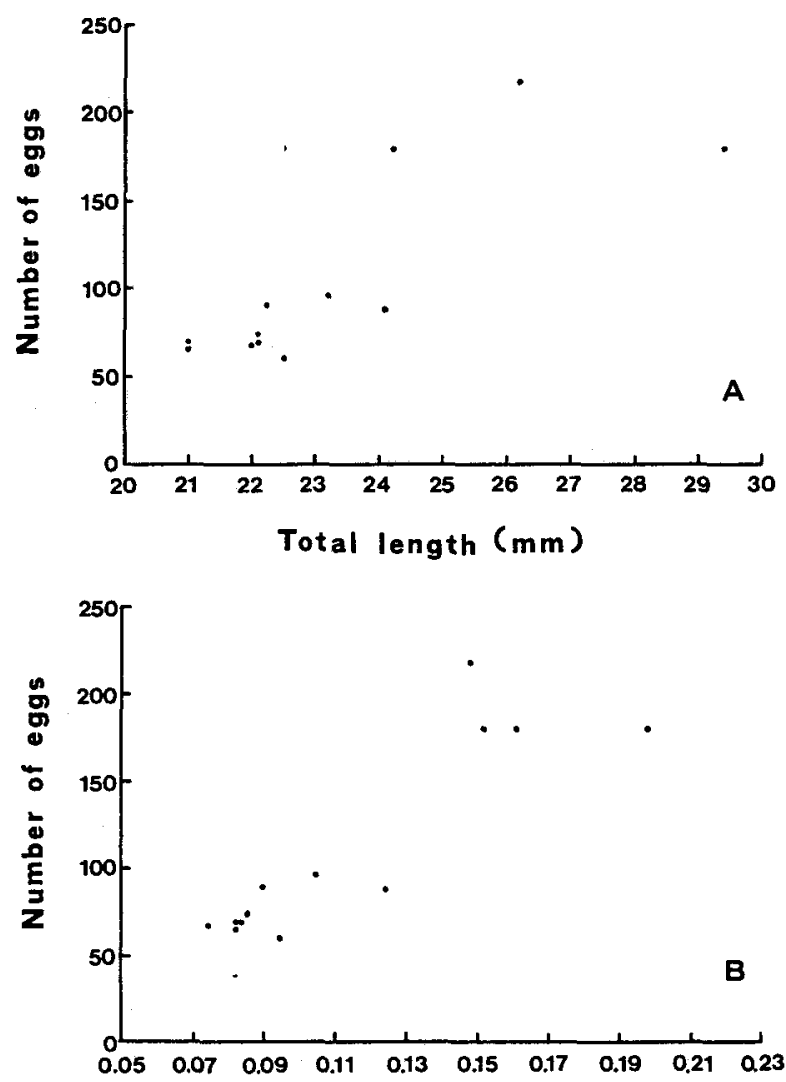

Total woight ( $g$ )

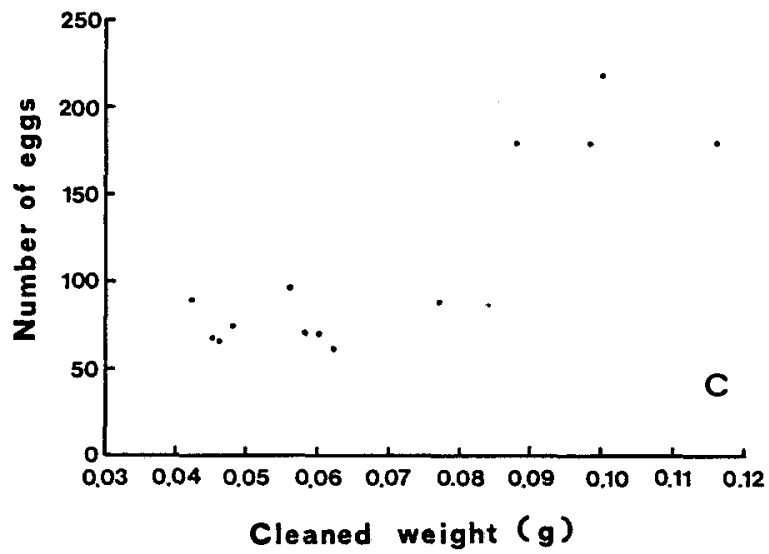

Fig. 5. Relation of fecundity (F) to A: total length (TL); B: total weight (TW) and C: cleaned weight (CW) in Knipowitschia caucasica 
food organisms, in both number and occurrence, and given here in the order of predominance, are Ficopomatus enigmaticus, Hediste diversicolor and Gammarus aequicauda; the participation of planktonic Crustacea and Abra ovata is very restricted. The predominant food organism in the A size group is G. aequicauda. F. enigmaticus is the most significant one in the rest of the food items; A. ovata, larvae of Diptera, $H$. diversicolor and planktonic Crustacea participate with small percentages. A higher percentage of unidentified organic material occurs in the A size group than it does in the B size group.

Table 3. Stomach contents of A and B size groups of Knipowitschia caucasica in the Evros Delta. Nf, $\%=$ number and percentage of fishes; $N, \%=$ number and percentage of individual items; $n r=$ not recorded

\begin{tabular}{|lrrrrrrrrr|}
\hline & \multicolumn{4}{c}{ Size group A } & \multicolumn{5}{c|}{ Size group B } \\
& $\begin{array}{l}\text { Frequency of } \\
\text { occurrence }\end{array}$ & No. of items & \multicolumn{3}{c|}{$\begin{array}{c}\text { Frequency of } \\
\text { occurrence }\end{array}$} & No. of items \\
& $\mathrm{Nf}$ & $\%$ & $\mathrm{~N}$ & $\%$ & & $\mathrm{Nf}$ & $\%$ & $\mathrm{~N}$ & $\%$ \\
\hline Gammarus aequicauda & 32 & 15.2 & 34 & 57.6 & 20 & 12.0 & 24 & 18.1 \\
Planktonic Crustacea & 1 & 0.5 & 1 & 1.7 & 3 & 1.8 & 8 & 6.0 \\
Ficopomatus enigmaticus & 7 & 3.3 & 12 & 20.3 & 38 & 22.8 & 72 & 54.1 \\
Hediste diversicolor & 1 & 0.5 & 1 & 1.7 & 27 & 16.2 & 27 & 20.3 \\
Abra ovata (juv.) & 2 & 1.0 & 7 & 11.9 & 1 & 0.6 & 2 & 1.5 \\
Larvae of Diptera & 4 & 1.9 & 4 & 6.8 & - & - & - & - \\
Unidentified organic matter & 39 & 18.5 & $\mathrm{nr}$ & - & 17 & 10.2 & $\mathrm{nr}$ & - \\
Empty stomachs & 128 & 60.7 & & & 73 & 43.7 & & \\
Number of fish examined & 211 & & & & 167 & & & \\
\hline
\end{tabular}

The monthly analysis of stomach contents of the whole $K$. caucasica population during the sampling period (Feb. 1983 - Feb. 1984) based on the occurrence method has been given by Kevrekidis \& Koukouras (1989, in press).

During the study period, the density of $H$. diversicolor in the sampling area exhibited a gradual decline from February (mean value 335.4 ind. $/ 400 \mathrm{~cm}^{2}$ ) to May (mean value 99.4 ind./400 $\mathrm{cm}^{2}$ ) and June, 1983 (mean value 6.2 ind./400 $\mathrm{cm}^{2}$ ) (Kevrekidis, 1988); in June 1983 - February 1984 its mean values varied between 6.2 ind. $/ 400 \mathrm{~cm}^{2}$ and 42.6 ind. $/ 400 \mathrm{~cm}^{2}$. The seasonal variation of the abundance of $G$. aequicauda in the study area is characterized by three phases: In February - June 1983 it had low values (mean values $1.4-5.2$ ind. $/ 400 \mathrm{~cm}^{2}$ ), in August - November 1983 it peaked (mean values 258.6 348.2 ind. $/ 400 \mathrm{~cm}^{2}$ ) and in November 1983 - February 1984 it decreased (mean values $93.2-107.4$ ind./400 $\mathrm{cm}^{2}$ ) (Kevrekidis, 1988; Kevrekidis \& Koukouras, 1989, in press).

\section{DISCUSSION}

In the Evros Delta, Knipowitschia caucasica grows rapidly in the summer and autumn after hatching. It matures after its first winter, breeds from the end of April to the end of July and grows rapidly again in July - September. The older males perish after their second February, whereas some females have a second breeding season at the end of April/beginning of May, shortly before their death. 
It has been hinted that some other populations of $K$. caucasica have a life span of about one year (Iljin, 1927, cited in Gheorghiev, 1964; Suvorov, 1948, cited in Baimov, 1963; Berg, 1949, cited in Gheorghiev, 1964; Koblitskaya, 1961, cited in Baimov, 1963); in the Aral Sea, it had a life cycle of one year with a small number of individuals surviving for a few months more (Baimov, 1963), while some individuals taken from the Bulgarian coasts of the Black Sea lived in an aquarium for from one year and half to two years (Gheorghiev, 1964). A short life span and early maturation may characterize all the Knipowitschia species (e.g. Gheorghiev, 1966; Gandolfi, 1972), as well as the Pomatoschistus species (e.g. Miller, 1961; Muus, 1967; Claridge et al., 1985), whereas a long life span and late maturation characterizes the genus Gobius (e.g. Miller, 1961; Gibson, 1970).

Information given on the populations of $K$. caucasica from different geographical areas, as far as growth rate is concerned (e.g. Koblitskaya, 1961, cited in Baimov, 1963; Baimov, 1963) seems to agree with the annual cycle of $K$. caucasica in the Evros Delta.

The beginning and the duration of the reproductive period seem to more or less vary among the populations of $K$. caucasica. Thus, $K$. caucasica in the Caspian Sea, at the preestuary of the Volga, breeds from the middle of April to the end of May and only rarely to June (Koblitskaya, 1957, 1961, cited in Baimov, 1963); in the Aral Sea from the beginning of May to the beginning of August (Baimov, 1963); in the Black Sea, on the Bulgarian coasts, from March to the end of July (Gheorghiev, 1964, 1966); in the North Aegean Sea, at the Evros Delta, from the end of April to the end of July.

The above observations that $K$. caucasica exhibits an annual cycle in growth rate and breeds during spring and summer having a $2-5$ month breeding season is common for many northern and temperate-zone gobiids (e.g. Miller, 1961; Muus, 1967; Gibson \& Ezzi, 1978). As far as the reproductive period is concerned, similar observations have also been made for the other species of the genus Knipowitschia (e.g. Gheorghiev, 1966; Gandolfi, 1972; Zelenin \& Vladimirov, 1975; Ragimov, 1986).

Knipowitschia species are small fish, their maximum length usually not exceeding $50 \mathrm{~mm}$ (e.g. Baimov, 1963; Miller, 1972; Pinchuk, 1978; Ragimov, 1986). The maximum weight of $K$. caucasica female recorded by Baimov (1963) in the Aral Sea (430 mg) is lower than it is in the Evros Delta (624 mg total weight, $474 \mathrm{mg}$ cleaned weight), but the maximum weight of males in the Aral Sea $(406 \mathrm{mg})$ is higher than that in our study (169 $\mathrm{mg}$ total weight, $138 \mathrm{mg}$ cleaned weight). The maximum weight reported by Sattarov (1972) in the Sukhandarya river basin is $295 \mathrm{mg}$, and by Troitskii \& Tsunikova (1978) in the Kuban Estuaries $980 \mathrm{mg}$.

The condition factor values calculated on the basis of cleaned weight in the population of the Aral Sea, which varied from 0.90 to 1.35 in juveniles, from 1.20 to 1.55 in mature males and from 1.23 to 1.34 in mature females (Baimov, 1963), are higher than those in the population of the Evros Delta. This suggests that in the Aral Sea the habitat offered better conditions for the $K$. caucasica population and the fish were heavier for their length than in the Evros Delta.

The conditions prevailing in the study area should be considered as favorable for $K$. caucasica spawning, according to the relevant literature. According to Baimov (1963), Ragimov (1986) and other authors, its spawning usually takes place in slightly moving shallow waters having a depth of $0.15 \mathrm{~m}$ to $1.5 \mathrm{~m}$, temperature from $15^{\circ} \mathrm{C}$ to $27^{\circ} \mathrm{C}$, salinity that may fluctuate within wide limits. Its eggs are usually attached to the underside of 
small gravels, dead bivalve shells, dead roots of reeds, etc. (e.g. Koblitskaya, 1961, cited in Baimov, 1963; Baimov, 1963; Gheorghiev, 1964, 1966; Ragimov, 1986).

In the Evros Delta, the ripe females of $K$. caucasica were generally shorter and lighter than those in other waters. The length of the ripe females in the Black Sea, on the Bulgarian coasts, ranged from $25 \mathrm{~mm}$ to $39 \mathrm{~mm}$ (Gheorghiev, 1964, 1966); in the Kuban estuaries generally from $24 \mathrm{~mm}$ to $38 \mathrm{~mm}$ (Troitskii \& Tsunikova, 1978); in the Aral Sea from $20.1 \mathrm{~mm}$ to $35.0 \mathrm{~mm}$ (Baimov, 1963); at the estuary and the Volga Delta from $20.1 \mathrm{~mm}$ to $45.0 \mathrm{~mm}$ (Koblitskaya, 1961, cited in Baimov, 1963). In the Caspian Sea also, Ragimov (1986) reported ripe females having a standard length of $27 \mathrm{~mm}$ to $31 \mathrm{~mm}$ and a weight of $0.462 \mathrm{~g}$ to $0.650 \mathrm{~g}$. Our observation that the mean fecundity of female $K$. caucasica generally increases with the size of the fish seems to be true also for other populations of this species (e.g. Koblitskaya, 1961, cited in Baimov, 1963; Baimov, 1963; Ragimov, 1986), as well as for other species of the genus Knipowitschia (e.g. Ragimov, 1986). Consequently, it is expected that the fecundity we recorded for $K$. caucasica is lower than it is in other areas. The fecundity of $K$. caucasica in the Black Sea varies from 358 to 1389 eggs (Gheorghiev, 1964, 1966); in the Kuban estuaries from 310 to 1083 with a mean of 702 eggs (Troitskii \& Tsunikova, 1978); in the Aral Sea from 97 to 343 with a mean of 186 eggs (Baimov, 1963); in the Caspian Sea, from 209 to 786 with a mean of 423 eggs (Savvaitova, 1959, cited in Baimov, 1963; Koblitskaya, 1961, cited in Baimov, 1963), from 209 to 382 with a mean of 285 eggs (Berg, 1949, cited in Baimov, 1963) and from 527 to 863 eggs with a mean of 715.6 (Ragimov, 1986). Nevertheless, the relative fecundity (RF) of $K$. caucasica in the Evros Delta is higher than that in the Caspian Sea, where Ragimov (1986) recorded a mean RF in different size groups ranging from 1249.38 to 1497.64.

The results of this study and the revision of the relevant literature show that the maximum individual fecundity of $K$. caucasica ranges from 217 to 1389 eggs. In $K$. longecaudata (Kessler, 1877), the corresponding values observed are from 350 to 2045 eggs (Zelenin \& Vladimirov, 1975; Ragimov, 1986), while in K. iljini (Berg, 1931) 2240 eggs (Ragimov, 1986). Values of individual fecundity analogous to that found in the present study have been recorded for other gobiids (e.g. Ragimov, 1986); however, in many species (mainly large-sized ones), very high maximum values have been recorded (e.g. up to 9-12 000) (e.g. Miller, 1961; Gibson, 1970; Gibson \& Ezzi, 1978). Finally, in the Caspian Sea, Ragimov (1986) reported a high relative fecundity for $K$. iljini (mean value 1932.53), and a generally lower RF for $K$. longecaudata (1037.04-1376.14) than for $K$. caucasica.

The analyses of the stomach contents showed that in the Evros Delta $K$. caucasica appears to be almost exclusively a bottom-feeder, preying predominantly on benthic amphipods and polychaetes. In other regions, the fish appears to eat both benthic and planktonic organisms; its food was composed mainly of amphipods, chironomid larvae, copepod crustaceans, cladoceran crustaceans, etc. (e.g. Koblitskaya, 1961, cited in Baimov, 1963; Baimov, 1963; Gheorghiev, 1964; Troitskii \& Tsunikova, 1978). The diet of $K$. longecaudata in the Danube basin consisted predominantly of chironomid larvae, corophiid amphipods and other crustaceans (Zelenin \& Vladimirov, 1975). Benthic amphipods and polychaetes are usually important prey organisms for many inshore and estuarine gobiids (Muus, 1967; Miller, 1969; Gibson, 1970; Claridge et al., 1985). In the study area, the smaller individuals of $K$. caucasica (size group A) consumed the amphipod 
Gammarus aequicauda more than any other prey, whereas in the larger ones (size group B) polychaetes (Ficopomatus enigmaticus, Hediste diversicolor) dominated. This should not be mainly attributed to different preferences among the larger and smaller individuals, but rather to a combination of the following: (1) The preference of all individuals for the more active amphipods (Magnhagen \& Wiederholm, 1982), and (2) the sharp increase of $G$. aequicauda density and the sharp decline of the polychaete $H$. diversicolor density recorded in the study area during the period of the A size group appearance (June August 1983) (Kevrekidis, 1988; Kevrekidis \& Koukouras, 1989, in press).

Finally, taking into account all the above, and in accordance with Baimov (1963), we can say that Knipowitschia caucasica has, besides its euryhaline nature, also other characteristic properties such as early maturity and polyphagous nutrition, which could account for its wide geographical and ecological distribution.

Acknowledgements. This study was partially supported by the Greek Ministry of Agriculture to which we express our gratitude. For the critical reading of the manuscript we thank Professor Dr. D. H. H. Kühlmann.

\section{LITERATURE CITED}

Bagenal, T. B. \& Braum, E., 1971. Eggs and early life history. In: Methods for assessment of fish production in fresh waters. Ed. by W. E. Ricker, Blackwell, Oxford, 166-198.

Baimov, U., 1963. Data on the biology of the bubyr goby Bubyr caucasicus (Berg) in the Aral Sea. Vest. Kav. Fil. Akad. Nauk Uz. S.S. R. 3 (13), 51-59.

Cancela da Fonseca, J. P., 1965. L'outil statistique en biologie du sol. I. Distributions de fréquences et tests de signification. - Revue Ecol. Biol. Sol 11, 299-332.

Claridge, P. N., Hardisty, M. W., Potter, I. C. \& Williams, C. V., 1985. Abundance, life history and ligulosis in the gobies (Teleostei) of the inner Severn estuary. - J. mar. biol. Ass. U.K. 65, 951-968.

Economidis, P. S., 1974. Etude merphologique, systématique et zoogéographique des poissons d'eau douce de la Macédoine orientale et de la Thrace occidentale (régions grecques). Thesis, Univ. Thessaloniki, $179 \mathrm{pp}$.

Economidis, P. S. \& Sinis, A. I., 1982, Les poissons du système des lacs koronia et Volvi (Macédoine, Grèce). Considérations systématiques et zoogéographiques. - Biol. Gallo-Hellen. 9, 291-316.

Economidis, P. S. \& Voyadjis, V. P., 1985. Les poissons des systèmes d'Axios-Doirani et de Gallikos (Macédoine, Grèce). - Biol. Gallo-Hellen. 10, 89-93.

Gandolfi, G., 1972. Osservazioni sul comportamento riproduttivo di Knipowitschia panizzae (Osteichthyes, Gobiidae). - Boll. Zool. 39, 621-622.

Gheorghiev, J. M., 1964. Some new and little known bullheads (Gobiidae, Pisces) to Bulgarian ichthyofauna. - Bull. Inst. Pisc. Pêch., Varna 4, 189-206.

Gheorghiev, J. M., 1966. Composition d'espèce et caractéristique des Gobiidés (Pisces) en Bulgarie. - Proc. Res. Inst. Fish. Oceanogr., Varna 7, 159-228.

Gibson, R. N., 1970. Observations on the biology of the giant goby Gobius cobitis Pallas. - J. Fish Biol. 2, 281-288.

Gibson, R. N. \& Ezzi, I. A., 1978. The biology of a Scottish population of Fries' goby, Lesueurigobius friesii. - J. Fish Biol. 12, 371-389.

Harding, J. P., 1949. The use of probability paper for the graphical analysis of polymodal frequency distributions. - J. mar. biol. Ass. U.K. 28, 141-153.

Hyslop, E. J., 1980. Stomach contents analysis - a review of methods and their application. - J. Fish Biol. 17, 411-429.

Kevrekidis, T., 1988. Bionomic study of the benthic amphipod populations in the Evros Delta, with special reference to the Gammarus aequicauda (Martynov) populations. Thesis, Univ. Thessaloniki, $176 \mathrm{pp}$.

Kevrekidis, T. \& Koukouras, A., 1989. Seasonal variation of abundance of Gammarus aequicauda (Crustacea: Amphipoda) in the Evros Delta (N. E. Greece). - Israel J. Zool. 36 (in press). 
Lagler, K. F., 1972. Freshwater fishery biology. Brown, Dubuque, $421 \mathrm{pp}$.

Le Cren, E. D., 1951. The length-weight relationship and seasonal cycle in gonad weight and condition in the perch (Perca fluviatilis). - J. Anim. Ecol. 20, 201-219.

Magnhagen, C. \& Wiederholm, A. M., 1982. Food selectivity versus prey availability: A study using the marine fish Pomatoschistus microps. - Oecologia 55, 311-315.

Mayrat, A., 1965. Calcul et comparaison des droites d'allométrie de croissance. - C.r. Soc. Biol. 159, 2139-2143.

Miller, P. J., 1961. Age, growth, and reproduction of the rock goby, Gobius paganellus L., in the Isle of Man. - J. mar. biol. Ass. U.K. 41, 737-769.

Miller, P. J., 1969. Systematics and biology of the leopard-spotted goby, Gobius ephippiatus (Teleostei: Gobiidae), with description of a new genus and notes on the identity of G. macrolepis Kolombatovic. - J. mar. biol. Ass. U.K. 49, 831-855.

Miller, P. J., 1972. Gobiid fishes of the Caspian genus Knipowitschia from the Adriatic Sea. - J. mar. biol. Ass. U.K. 52, 145-160.

Muus, B. J., 1967. The fauna of Danish estuaries and lagoons. - Meddr Danm. Fisk. og Havunders. S, $1-316$.

Nikolsky, G. V., 1963. The ecology of fishes. Acad. Press, London, $352 \mathrm{pp}$.

Nikolsky, G. V., 1969. Theory of fish population dynamics as the biological background for rational exploitation and management of fishery resources. Oliver \& Boyd, Edinburgh, 323 pp.

Papaconstantinou, C., 1988. Fauna Graeciae. IV. Check-list of marine fishes of Greece. National Centre for Marine Research, Hellenic Zoological Society, Athens, $257 \mathrm{pp}$.

Papaconstantinou, C. \& Tortonese, E., 1980. On a collection of fishes from Thermaikos Gulf (N.E. Greece). - Thalassographica 3 (2), 15-42.

Pinchuk, V. I., 1978. A new species of goby from the western part of the Black Sea, Knipowitschia georghievi Pinchuk, sp.n. (Gobiidae, Pisces). - Zool. Zh. 57, 796-799.

Ragimov, D. B., 1986. On the reproduction of small species of Gobiidae from the Caspian Sea. Vopr. Ikht. 26, 937-944.

Sattarov, K. S., 1972. Pomatoschistus caucasicus in the Sukhandarya river basin. - Uzbek. biol, Zh. $16(3), 51-52$.

Tesch, F. W., 1971. Age and growth. In: Methods for assessment of fish production in fresh waters. Ed. by W. E. Ricker, Blackwell, Oxford, 98-130.

Tortonese, E. (Ed.), 1975. Fauna d'Italia. Osteichthyes (Pesci Ossei). Calderini, Bologna, 2, 1-636.

Troitskii, S. K. \& Tsunikova, E. P., 1978. Biology of Pomatoschistus caucasicus (Pisces, Gobidae) in Kuban estuaries, - Vest. Zool. 5, 85-87.

Zar, J. H., 1984. Biostatistical analysis. Prentice-Hall, Englewood Cliffs, 718 pp.

Zelenin, A. M. \& Vladimirov, M. Z., 1975. New data on the distribution and biology of the goby Knipowitschia Iongicaudata (Kessler) in the Danube basin USSR. - Izv. Akad. Nauk Mold. SSR (Ser. Biol. Khim. Nauk) 5, 44-46.

Zerunian, S. \& Gandolfi, G., 1986. Considerazioni sui gobidi d'acqua dolce presenti nel Basso Lazio (Fisces, Gobiidae). - Riv. Idrobiol. 25, 69-80. 